\title{
PENGARUH KOMPETENSI DOSEN, MOTIVASI B ELAJAR DAN INDEKS PRESTASI KUMULATIF TERHADAP KETERAMPILAN PEMASANGAN ALAT KONTRASEPSI DALAM RAHIM OLEH MAHASISWA PRODI D3 KEBIDANAN UNISSULA SEMARANG
}

\author{
Is Susiloningtyas ${ }^{1}$ \\ Email: issusiloningtyas@ gmail.com \\ ${ }^{1}$ Staf Pengajar Prodi D3 Kebidanan Fakultas Kedokteran Universitas Islam Sultan Agung \\ Semarang Jln. Raya Kaligawe KM.4 Semarang Telp (024) 6594366
}

\begin{abstract}
Abstrak
Dari hasil uji kompetensi keterampilan pemasangan alat kontrasepsi dalam rahim mahasiswa semester IV Prodi D3 Kebidanan Unissula masih ada 10\% mahasiswa yang belum kompeten. Berdasarkan hasil kajian teori terhadap masalah tersebut, diduga disebabkan oleh rendahnya kompetensi dosen, motivasi belajar dan IPK mahasiswa. Untuk itu dilakukan penelitian yang bersifat deskriptif analitik dengan metode potong lintang. Jumlah sampel 72 responden, pengolahan statistik menggunakan uji korelasi Pearson dan dilanjutkan dengan analisis jalur.

Penelitian ini bertujuan untuk mengetahui pengaruh kompetensi dosen, motivasi belajar dan IPK terhadap keterampilan pemasangan alat kontrasepsi dalam rahim mahasiswa Prodi D3 Kebidanan Unissula Semarang.

Hasil penelitian menunjukkan bahwa kompetensi dosen mempunyai pengaruh langsung terhadap keterampilan pemasangan alat kontrasepsi dalam rahim sebesar 45.8\%, motivasi belajar mempunyai pengaruh langsung terhadap keterampilan pemasangan alat kontrasepsi dalam rahim sebesar $49.0 \%$ dan IPK mempunyai pengaruh langsung terhadap keterampilan pemasangan alat kontrasepsi dalam rahim sebesar 20.7\%. Sedangkan berdasarkan analisis jalur kompetensi berpengaruh secara parsial sebesar $38.8 \%$, motivasi sebesar $27.3 \%$ dan IPK sebesar $13.8 \%$. Secara simultan pengaruh kompetensi dosen, motivasi belajar mahasiswa dan IPK terhadap keterampilan pemasangan alat kontrasepsi dalam rahim sebesar $79.9 \%$.
\end{abstract}

Kata kunci : Kompetensi dosen, Motivasi belajar, IPK, Keterampilan pemasangan alat kontrasepsi dalam rahim

\section{Pendahuluan}

Alat Kontrasepsi Dalam Rahim (AKDR) merupakan metode yang efektif untuk menunda dan mengatur kehamilan, tetapi Pasangan Usia Subur (PUS) masih belum tertarik untuk menggunakan AKDR. Menurut laporan Badan Koordinator Keluarga Berencana Nasional (BKKBN) tahun (2012), pada umumnya PUS yang menjadi akseptor Keluarga Berencana (KB) menggunakan: (1) pil; (2) suntik; (3) kondom. ${ }^{1}$

Sebaliknya PUS yang menggunakan alat kontrasepsi jenis MKJP masih rendah yaitu sebesar $10.9 \%$. Pada umumnya MKJP yang digunakan PUS antara lain: (1) Medis Operatif Wanita (MOW) sebesar 3\%; (2) Medis Operatif Pria (MOP) sebesar $0.2 \%$; (3) AKDR sebesar 4.9\%; (4) implant sebesar $2.8 \%{ }^{1}$

Hasil kajian teoritis, diketahui faktorfaktor yang memengaruhi akseptor dalam memilih alat kontrasepsi, antara lain pertimbangan medis, latar belakang sosial budaya, sosial ekonomi, pengetahun, pendidikan. Faktor penting lain yang berpengaruh secara tidak langsung terhadap pemakaian alat kontrasepsi adalah akses pelayanan, kualitas pelayanan KB dan penerimaan pemakaian alat kontrasepsi. Pengaruh kualitas pelayanan $\mathrm{KB}$, disini adalah pandangan klien tentang pelayanan pemakaian alat kontrasepsi yang diterima yaitu pemilihan metode, pemberian informasi $\mathrm{KB}$, hubungan interpersonal, serta kemampuan teknis petugas. ${ }^{2}$

Untuk menghasilkan tenaga bidan yang bermutu dan memiliki kemampuan komprehensif, profesional, Departemen Kesehatan Republik Indonesia (Depkes RI) membuat kebijakan tentang Standar Pelayanan Kebidanan (SPK) yang mengatur, bidan harus memberikan asuhan kebidanan yang bermutu tinggi dalam Pra 
Konsepsi, KB, dan ginekologi, hal ini dapat disiapkan melalui instansi pendidikan tenaga kesehatan yang berkualitas ${ }^{3}$. Hal ini didukung oleh pernyataan Tandelilin E (2005) bahwa, untuk mendapatkan keluaran pendidikan berkualitas, berbagai unsur input seperti raw input (peserta didik) dan instrumental input (kurikulum, sarana dan prasarana pendidikan, tenaga pengajar dan tenaga administrasi) harus berjalan secara efektif dan efisien didalam proses pembelajaran. ${ }^{4}$

Berdasarkan laporan akademik mahasiswa Prodi D3 Kebidanan Universitas Islam Sultan Agung (Unissula) Semarang terhadap hasil uji kompetensi keterampilan pemasangan AKDR pada mata kuliah asuhan kebidanan pelayanan $\mathrm{KB}$ yang dilaksanakan pada akhir semester IV, ternyata masih ada 10\% mahasiswa yang belum kompeten didalam keterampilan pemasangan AKDR, sedangkan dinyatakan kompeten apabila mahasiswa pada saat uji kompetensi mendapatkan nilai batas lulus 70 berdasarkan standar Prodi D3 Kebidanan Unissula Semarang. ${ }^{5}$

Penelitian United State Agency International Development ( USAID) pada tahun 2009 mengenai program evaluasi pralayanan pendidikan kebidanan di Afganistan, menunjukkan bahwa kompetensi yang dimiliki oleh para lulusan cukup baik dalam praktik pelaksanaan pemeriksaan kehamilan dan pertolongan persalinan. Keterampilan lulusan masih dianggap kurang dalam penatalaksanaan kasus kegawatdaruratan obstetri, misal penanganan syok $(25 \%)$ dan pengeluaran placenta secara manual (39\%). Para lulusan menyatakan bahwa tidak semua meteri dan keterampilan yang diberikan selama perkuliahan dapat diaplikasikan langsung saat bekerja. Para lulusan menilai bahwa perlu penambahan materi keterampilan dalam pemasangan alat kontrasepsi terutama AKDR serta pelayanan kebidanan komunitas. ${ }^{6}$

Fenomena rendahnya pencapaian kompetensi pemasanganAKDR di Prodi D3 Kebidanan Unissula Semarang diduga karena: (1) kompetensi dosen; (2) motivasi belajar mahasiswa;(3) Indeks Prestasi Kumulatif (IPK) mahasiswa dalam proses belajar mengajar yang kurang Secara teoritis kompetensi dosen merupakan kemampuan seseorang yang berbasis dari knowlegde, skill dan attitude yang harus dimiliki dan dikuasai oleh dosen dilihat dari kompetensi pedagogik, kompetensi kepribadian, kompetensi sosial dalam melaksanakan tugas ke profesionalannya ${ }^{7}$

Selain pengaruh kompetensi dosen, motivasi dari mahasiswa juga menentukan performance dari seorang mahasiswa. Berdasarkan penelitian Githa (2004) terhadap mahasiswa D3 Keperawatan, menyatakan terdapat hubungan yang positif dan signifikan antara motivasi berprestasi dan prestasibelajar. ${ }^{8}$

Keberhasilan mahasiswa selama mengikuti proses pembelajaran dapat dilihat dari penilaian tiap mata kuliah, penilaian semester, penilaian tahun akademik maupun penilaian akhir program. Nilai prestasi tiap mata kuliah merupakan hasil kumulatif nilai-nilai komponen tugas terstruktur, praktikum, ujian tengah semester dan ujian akhir semester. Penelitian Supriatna menunjukkan bahwa nilai Indeks Prestasi Kumulatif (IPK) dapat digunakan sebagai prediktor keberhasilan belajar mahasiswa. ${ }^{9}$

\section{Metode Penelitian}

Jenis penelitian ini adalah penelitian deskriptif analitik korelatif dengan pendekatan potong lintang dan menggunakan analisis jalur (Path Analysis). ${ }^{10}$ Sampel dalam penelitian ini adalah semua mahasiswa D3 Kebidanan Unissula Semarang semester V Tingkat III yang berjumlah 72 mahasiswa. Karena keterbatasan sampel, maka seluruh populasi digunakan sebagai sampel penelitian. ${ }^{11}$

Kriteria inklusi penelitian adalah Mahasiswa Kebidanan Unissula Semarang semester V Tingkat III dan mahasiswa yang sudah lulus pada mata kuliah askeb KB, sedangkan kriteria eksklusi dalam penelitian ini adalah mahasiswa yang belum menyelesaikan mata kuliah askeb KB, tidak bersedia menjadi subjek penelitian.

Variabel bebas dalam penelitian adalah kompetensi dosen, motivasi belajar mahasiswa dan IPK mahasiswa, sedangkan variabel terikat penelitian ini adalah keterampilan mahasiswa dalam pemasangan 
AKDR. Pengambilan data kompetensi dosen dan motivasi belajar mahasiswa menggunakan kuesioner dengan skala Likert yang diisi oleh mahasiswa, sedangkan untuk keterampilan mahasiswa dalam pemasangan AKDR data diambil dengan menggunakan cheklist dimana mahasiswa melakukan praktik langsung pemasangan AKDR di laboratorium.

Analisis data menggunakan uji korelasi Pearson yaitu untuk mengetahui pengaruh kompetensi dosen terhadap keterampilan mahasiswa didalam pemasangan AKDR, untuk mengetahui pengaruh motivasi belajar terhadap keterampilan mahasiswa didalam pemasangan AKDR,untuk mengetahui pengaruh IPK mahasiswa terhadap keterampilan mahasiswa didalam pemasangan AKDR yang dilanjutkan menggunakan analisis jalur untuk mengetahui seberapa besar pengaruh langsung maupun tidak langsung dari kompetensi dosen, motivasi belajar dan IPK mahasiswa terhadap keterampilan mahasiswa didalam pemasangan AKDR.

\section{Hasil Dan Pembahas an}

Tabel 1. Korelasi antara kompetensi dosen, motivasi belajar dan IPK mahasiswa terhadap keterampilan mahasiswa dalam pemasangan AKDR

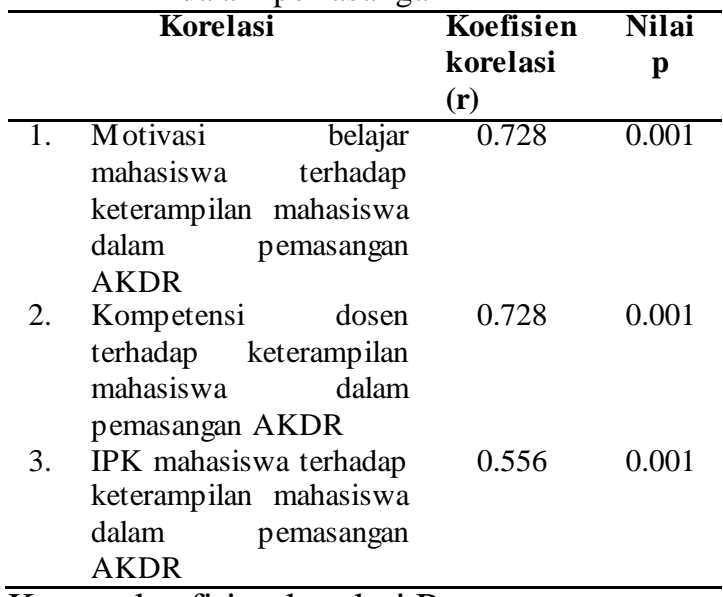

Ket: $\mathrm{r}=$ koefisien korelasi Pearson

Berdasarkan Tabel 1 menunjukkan bahwa motivasi belajar mahasiswa dan kompetensi dosen mempunyai korelasi yang kuat dan bermakna terhadap keterampilan mahasiswa dalam pemasangan AKDR, dan IPK mahasiswa mempunyai korelasi yang sedang dan bermakna terhadap keterampilan pemasangan AKDR.

Pengaruh secara parsial dapat diketahui bahwa kompetensi dosen dengan nilai 38,8\% lebih dominan memengaruhi keterampilan pemasanganAKDR daripada variabel motivasi belajar dan IPK mahasiswa. Berdasarkan tesis Sahyar menyatakan bahwa kompetensi dosen dan proses pembelajaran berpengaruh signifikan terhadap kepuasan mahasiswa. ${ }^{12} \mathrm{Hal}$ ini juga sejalan dengan penelitian Marhawati yang menyatakan bahwa kompetensi professional mempunyai pengaruh yang signifikan terhadap kinerja dosen. ${ }^{13}$

Dalam dunia pendidikan, keberadaan dosen merupakan salah satu faktor yang sangat berperan penting dalam proses belajar mengajar, dimana dosen merupakan ujung tombak dalam mencapai tujuan pendidikan hal ini karena dosen langsung berinteraksi dengan mahasiswa sebagai subjek didik. Penyelenggaraan pendidikan dikatakan berhasil apabila dosen mempunyai kemampuan dasar dalam mengajar, kesiapan yang matang dalam melaksanakan kegiatan proses belajar mengajar. Dosen sebagai perancang pengajaran, manajer pengajaran, pengarah belajar mengajar, pembimbing serta pendidik dan penilai hasil belajar, maka merekalah yang sesungguhnya paling mengetahui perkembangan peserta didik sejak dari awal sampai akhir proses pendidikan. $^{14}$

Profesi dosen merupakan bidang pekerjaan khusus yang dilaksanakan berdasarkan prinsip memiliki kualifikasi akademik dan latar belakang pendidikan sesuai dengan bidangnya dan memiliki kompetensi dosen yang diperlukan antara lain Kompetensi Pedagogik, kompetensi Profesional, Kompetensi Kepribadian dan Kompetensi sosial?.

Tabel 2. Korelasi antara kompetensi dosen, motivasi belajar dan IPK mahasiswa

\begin{tabular}{llcc}
\hline Korelasi & $\begin{array}{c}\text { Koefisien } \\
\text { korelasi } \\
(\mathbf{r})\end{array}$ & Nilai p \\
\hline 1. & $\begin{array}{l}\text { Motivasi belajar } \\
\text { mahasiswa dengan } \\
\text { kompetensi dosen }\end{array}$ & 0.373 & 0.001 \\
& & \\
\end{tabular}


2. IPK mahasiswa $0.417 \quad 0.001$ dengan

kompetensi dosen

3. IPK mahasiswa dengan motivasi

0.006 belajar mahasiswa

Ket: $r=$ koefisien korelasi Pearson

Berdasarkan Tabel 2 menunjukkan bahwa motivasi belajar mahasiswa dan IPK mahasiswa mempunyai korelasi yang sedang dan bermakna terhadap kompetensi dosen, dan IPK mahasiswa mempunyai korelasi yang sedang dan bermakna terhadap motivasi belajar mahasiswa.

Pengaruh motivasi terhadap keterampilan pemasangan AKDR sebesar $27,3 \%$. Hal ini berarti semakin berarti semakin tinggi motivasi belajar, maka semakin tinggi pula keterampilan mahasiswa dalam pemasangan AKDR. Dengan demikian, maka melalui motivasi belajar yang dimiliki oleh mahasiswa akan memberikan dampak positif bagi mahasiswa tersebut. Hasil penelitian sejalan dengan Nirwana (2003), yang menyatakan adanya hubungan antara motivasi dengan prestasi belajar diperantarai oleh kegiatan belajar. ${ }^{15}$

Berdasarkan Ramainas, mengatakan bahwa salah satu variabel yang berhubungan dengan hasil pembelajaran adalah motivasi terhadap prestasi. Motivasi ini mempunyai ciri dalam belajar selalu ingin berkembang dan maju mencapai keberhasilan, bekerja keras, dan memandang bahwa dari pekerjaan itu akan memperoleh kebanggaan pribadi, siap memperoleh resiko gagal. Hasil penelitian Ramainas (2006), mengatakan adanya hubungan antara motivasi belajar dengan hasil belajar memiliki linearitas tinggi, semakin tinggi skor motivasi belajar semakin tinggi hasil belajar. ${ }^{16}$

Penelitian yang dilakukan Suprapto, I (2006) menunjukkan bahwa ada hubungan yang erat dan signifikan antara motivasi berprestasi, kebiasaan belajar dan suasana akademik dengan prestasi belajar mahasiswa STKIP Muhammadiyah Kotabumi Lampung Utara tahun 2005.

Tabel 3. Pengaruh berbagai variabel secara simultan terhadap keterampilan

\begin{tabular}{|c|c|c|c|c|c|c|c|}
\hline & \multicolumn{5}{|c|}{$\begin{array}{l}\text { pemasanganAKDR } \\
\text { analisis jalur }\end{array}$} & \multicolumn{2}{|c|}{ berdas arkan } \\
\hline $\begin{array}{c}\text { Varia } \\
\text { bel }\end{array}$ & $\begin{array}{l}\text { Ko } \\
\text { ef }\end{array}$ & $\begin{array}{c}\text { SE } \\
(\mathrm{B} \\
)\end{array}$ & $\begin{array}{c}\text { K } \\
\text { oe } \\
\mathbf{f} \\
\text { jal } \\
\text { ur }\end{array}$ & $\begin{array}{c}\mathbf{T} \\
\text { hitu } \\
\text { ng }\end{array}$ & $\begin{array}{c}\text { T } \\
\text { ta } \\
\text { bel }\end{array}$ & $\begin{array}{c}\mathbf{N i} \\
\text { lai } \\
\mathbf{p}\end{array}$ & Ket \\
\hline $\begin{array}{l}\text { Motiv } \\
\text { asi } \\
\text { belaja } \\
\text { r } \\
\text { maha } \\
\text { siswa }\end{array}$ & $\begin{array}{l}0.4 \\
49\end{array}$ & $\begin{array}{l}0.0 \\
54\end{array}$ & $\begin{array}{l}0 . \\
49 \\
0\end{array}$ & $\begin{array}{l}8 . \\
34 \\
7\end{array}$ & $\begin{array}{l}1 . \\
6 \\
7\end{array}$ & $\begin{array}{l}0 . \\
00 \\
1\end{array}$ & $\begin{array}{l}\text { Signi } \\
\text { fikan }\end{array}$ \\
\hline $\begin{array}{l}\text { Kom } \\
\text { peten } \\
\text { si }\end{array}$ & $\begin{array}{l}0.2 \\
53\end{array}$ & $\begin{array}{l}0.0 \\
34\end{array}$ & $\begin{array}{l}0 . \\
45 \\
8\end{array}$ & $\begin{array}{l}7 . \\
48 \\
4\end{array}$ & $\begin{array}{l}1 . \\
6 \\
7\end{array}$ & $\begin{array}{l}0 . \\
00 \\
1\end{array}$ & $\begin{array}{l}\text { Signi } \\
\text { fikan }\end{array}$ \\
\hline IPK & $\begin{array}{l}5.2 \\
5\end{array}$ & $\begin{array}{l}1.5 \\
18\end{array}$ & $\begin{array}{l}0 . \\
20 \\
7\end{array}$ & $\begin{array}{l}3 . \\
45 \\
8\end{array}$ & $\begin{array}{l}1 . \\
6 \\
7\end{array}$ & $\begin{array}{l}0 . \\
00 \\
1\end{array}$ & $\begin{array}{l}\text { Signi } \\
\text { fikan }\end{array}$ \\
\hline $\begin{array}{l}\text { Konst } \\
\text { anta }\end{array}$ & $\begin{array}{l}- \\
17 . \\
45 \\
2\end{array}$ & $\begin{array}{l}5.5 \\
96\end{array}$ & & $\begin{array}{l}- \\
3 . \\
11 \\
9\end{array}$ & & $\begin{array}{l}0 . \\
00 \\
3\end{array}$ & \\
\hline
\end{tabular}

Ket: $\mathrm{r} 2$ multipel $=79.7 \%$

Jadi persamaan regresi : keterampilan pemasangan AKDR $=-17.452+$ $0.449 \times 0.449+0.253 \times 0.253+5.25 \times 5.25$.

Berdasarkan Tabel 3 menunjukkan bahwa berdasarkan analisis jalur didapatkan semua variabel bebas mempunyai koefisien jalur yang signifikan, yaitu koefisien jalur antara motivasi belajar mahasiswa terhadap keterampilan mahasiswa didalam pemasangan AKDR $\left(\mathrm{P}_{\mathrm{yx} 1}\right)$, koefisien jalur antara kompetensi dosen terhadap keterampilan mahasiswa didalam pemasangan AKDR $\left(\mathrm{P}_{\mathrm{y} \times 2}\right)$ dan koefisien jalur antara IPK mahasiswa terhadap keterampilan mahasiswa didalam pemasanganAKDR $\left(\mathrm{P}_{\mathrm{yx} 3}\right)$.

Pada Tabel 3 diatas juga menunjukkan bahwa semua koefisien jalur signifikan pada $\alpha=0.05$, karena semua $t$ hitung lebih besar daripada $t$ tabel. Sedangkan besarnya koefisien diterminan (kontribusi) $X_{1}, X_{2}$, dan $\mathrm{X}_{3}$ secara simultan terhadap $\mathrm{Y}$ sebesar 0.797 yang berarti bahwa $79.7 \%$, variasi keterampilan pemasangan AKDR dapat dijelaskan oleh motivasi belajar, kompetensi dosen dan IPK mahasiswa. Besar koefisien residu untuk $(\mathrm{Py}) \varepsilon=\sqrt{ }(1-0.797)=0.450$, merupakan pengaruh variabel lain diluar kompetensi dosen, motivasi belajar dan IPK 
mahasiswa, dan diagram jalurnya seperti pada gambar dibawah ini:

Gambar 1. Koefisien Jalur antara kompetensi dosen, motivasi belajar dan IPK mahasiswa terhadap keterampilan pemasangan AKDR

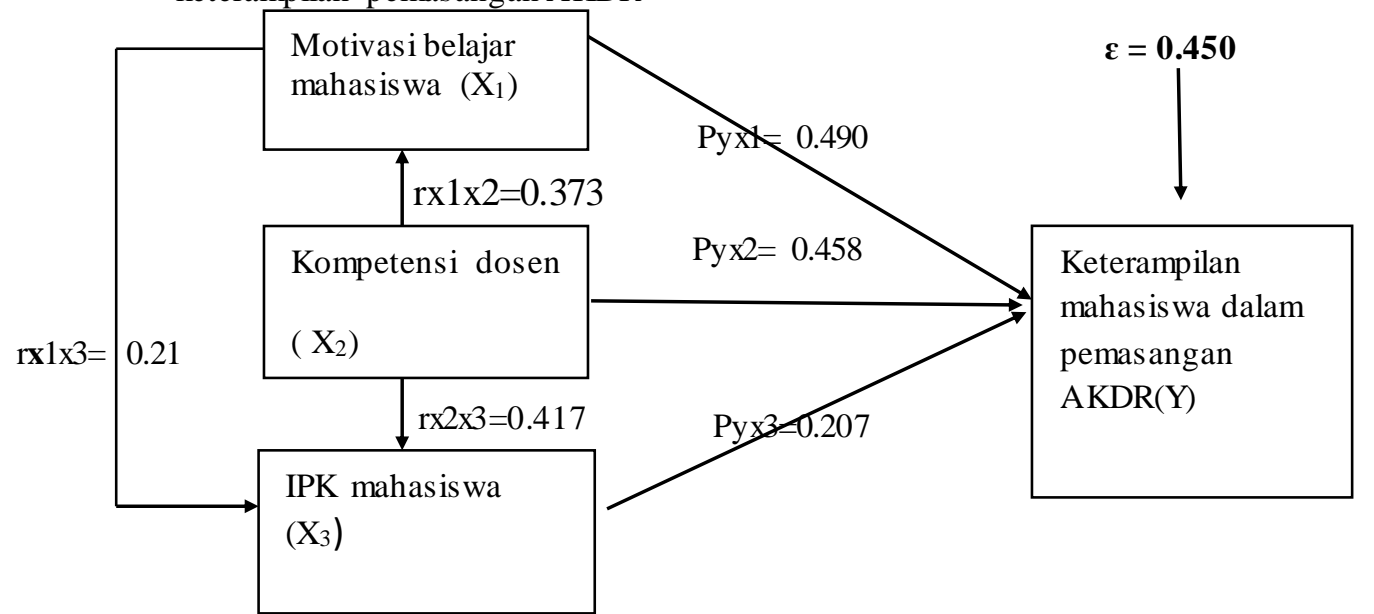

Berdasarkan Gambar 1 dimana :

rx1x2 : Koefisien korelasi antara X1 dan X2 sebesar 0.373

rx2x3 : Koefisien korelasi antara X2 dan X3 sebesar 0.321

rx1x3 : Koefisien korelasi antara X1 dan X3 sebesar 0.417

Pyx1 : Koefisien jalur pengaruh langsung X1 terhadap Y sebesar 0.490

Pyx2 : Koefisien jalur pengaruh langsung X2 terhadap Y sebesar 0.458

Pyx3 : Koefisien jalur pengaruh langsung X3 terhadap Y sebesar 0.207

$\varepsilon$ (error): variabel lain yang mempengaruhi Y sebesar 0.450

Dari hasil analisis jalur secara simultan pengaruh langsung dan tidak langsung antar variabel penelitian yaitu kompetensi dosen, motivasi belajar dan IPK mahasiswa terhadap keterampilan mahasiswa dalam pemasangan AKDR sebesar $79.7 \%$. Ini berarti bahwa kompetensi dosen, motivasi belajar dan IPK memiliki pengaruh yang positif dan signifikan terhadap keterampilan pemasangan AKDR diProdi D3 Kebidanan Unissula Semarang. Hal ini menggambarkan bahwa kompetensi dosen, motivasi belajar dan IPK mahasiswa akan menentukan trampil dan tidaknya mahasiswa didalam melakukan pemasangan AKDR.

Berdasarkan tesis Sahyar menyatakan bahwa kompetensi dosen dan proses pembelajaran berpengaruh signifikan terhadap kepuasan mahasiswa. Dalam dunia pendidikan, keberadaan dosen merupakan salah satu faktor yang sangat berperan penting dalam proses belajar mengajar, dimana dosen merupakan ujung tombak dalam mencapai tujuan pendidikan hal ini karena dosen langsung berinteraksi dengan mahasiswa sebagai subjek didik. ${ }^{12}$

Berdasarkan Ramainas, mengatakan bahwa salah satu variabel yang berhubungan

dengan hasil pembelajaran adalah motivasi terhadap prestasi. Motivasi ini mempunyai ciri dalam belajar selalu ingin berkembang dan maju mencapai keberhasilan, bekerja keras, dan memandang bahwa dari pekerjaan itu akan memperoleh kebanggaan pribadi, siap memperoleh resiko gagal. ${ }^{16}$

$$
\text { Penelitian Harniasih }
$$
menunjukkan bahwa ada hubungan antara minat belajar dengan indeks prestasi. ${ }^{18}$ Hasil penelitian ini sesuai pula dengan yang diungkapkan Slameto (2003) yang menyatakan bahwa minat besar pengaruhnya terhadap prestasi belajar, karena bila bahan pelajaran yang dipelajari tidak sesuai dengan minat siswa, siswa tidak akan belajar dengan sebaik-baiknya, karena tidak ada daya tarik baginya. ${ }^{20}$

Tabel 4. Besar pengaruh motivasi belajar mahasiswa terhadap keterampilan mahasiswa dalam pemasangan AKDR

\begin{tabular}{lc}
\hline $\begin{array}{l}\text { Pengaruh langsung dan } \\
\text { tidak langsung pada } \mathbf{Y}\end{array}$ & Koefisien jalur \\
\hline X1 langsung & $24.0 \%$ \\
X1 melalui X3 & $3.25 \%$ \\
$\begin{array}{l}\text { Total pengaruh X2 } \\
\text { pada Y }\end{array}$ & $\mathbf{2 7 . 2 5 \%}$ \\
\hline
\end{tabular}


Pada Tabel 4 dapat dilihat bahwa motivasi berpengaruh langsung terhadap keterampilan mahasiswa dalam pemasangan AKDR sebesar $24.0 \%$ dan berpengaruh tidak langsung melalui IPK mahasiswa $\left(\mathrm{X}_{3}\right)$ sebesar $3.25 \%$ Dengan demikian total pengaruh motivasi terhadap keterampilan mahasiswa dalam pemasangan AKDR sebesar 27.25\%.

Tabel 5. Besar pengaruh Kompetensi Dosen terhadap Keterampilan mahasiswa dalam Pemasangan AKDR

\begin{tabular}{lc}
\hline $\begin{array}{c}\text { Pengaruh langsung dan } \\
\text { tidak langsung pada }\end{array}$ & Koefisien jalur \\
\hline X2 langsung & $20.9 \%$ \\
X2 melalui X1 & $8.37 \%$ \\
X2 melalui X3 & $9.53 \%$
\end{tabular}

Total pengaruh $\mathrm{X} 1$ pada $\mathbf{Y}$

$\mathbf{3 8 . 8 \%}$

Pada Tabel 5 dapat dilihat bahwa kompetensi dosen berpengaruh langsung terhadap keterampilan mahasiswa dalam pemasangan AKDR sebesar 20.9\% dan berpengaruh tidak langsung melalui motivasi belajar $\left(\mathrm{X}_{2}\right)$ sebesar $8.37 \%$ sedangkan berpengaruh tidak langsung melalui IPK mahasiswa $\left(X_{3}\right)$ sebesar 9.53\%. Dengan demikian total pengaruh kompetensi dosen terhadap keterampilan mahasiswa dalam pemasangan AKDR sebesar 38.8\%.

Tabel 6. Besar pengaruh IPK mahasiswa terhadap keterampilan mahasiswa dalam pemasanganAKDR

Pengaruh langsung dan $\quad$ Koefisien jalur
tidak langsung pada $Y$

\begin{tabular}{ll}
\hline X3 langsung & $4.28 \%$ \\
X3 melalui X1 & $9.53 \%$. \\
& $13.81 \%$ \\
\hline
\end{tabular}

Berdasarkan Tabel 6 dapat dilihat bahwa IPK mahasiswa berpengaruh langsung terhadap keterampilan mahasiswa dalam pemasangan AKDR sebesar $4.28 \%$ dan berpengaruh tidak langsung melalui kompetensi dosen sebesar 9.53\%. Dengan demikian total pengaruh IPK mahasiswa terhadap keterampilan mahasiswa dalam pemasangan AKDR sebesar 13.81\%.
Hasil penelitian bahwa pengaruh IPK mahasiswa terhadap keterampilan mahasiswa dalam pemasangan AKDR sebesar 13.8\%. IPK mahasiswa merupakan angka yang menunjukkan prestasi atau kemajuan belajar mahasiswa dalam satu semester secara kumulatif dari semester pertama sampai semester paling akhir ditempuh.

Prestasi belajar mahasiswa dalam pendidikan kebidanan sangat penting untuk menilai tingkat keberhasilan dalam pencapaian tujuan belajar yang telah ditetapkan dalam kurikulum pendidikan kebidanan. Keberhasilan studi dan prestasi akademik mahasiswa berdasarkan komponenkomponen yang memengaruhi yaitu ujian tatap muka atau kehadiran di dalam ruang kelas maupun di laboratorium dan tugas rumah (baik struktur maupun mandiri). Ketiga komponen tersebut tidak dapat dipisahkan satu sama lain. ${ }^{17}$ Penelitian Harniasih (2005) menunjukkan bahwa ada hubungan antara minat belajar dengan indeks prestasi. ${ }^{18}$

Hasil penelitian ini sesuai pula dengan yang diungkapkan Slameto (2003) yang menyatakan bahwa minat besar pengaruhnya terhadap prestasi belajar, karena bila bahan pelajaran yang dipelajari tidak sesuai dengan minat siswa, siswa tidak akan belajar dengan sebaik-baiknya, karena tidak ada daya tarik baginya. ${ }^{19}$ Hal ini tentu akan memengaruhi prestasi belajar siswa. Keberhasilan mahasiswa didalam proses belajar bisa diprediksi oleh IPK sebelumnya.

\section{Kesimpulan}

Berdasarkan hasil penelitian yang telah dilakukan untuk mengetahui Pengaruh Kompetensi Dosen dan Motivasi Belajar Mahasiswa terhadap Keterampilan Mahasiswa dalam pemasangan AKDR di Prodi D3 Kebidanan Unissula Semarang, maka dapat ditarik simpulan sebagai berikut:

a. Kompetensi Dosen yang baik mempunyai pengaruh yang besar terhadap keterampilan pemasangan AKDR .

b. Motivasi belajar mahasiswa yang tinggi menghasilkan keterampilan pemasangan AKDR yang baik.

c. Mahasiswa yang mempunyai IPK yang baik menghasilkan keterampilan pemasangan AKDR yang baik. 


\section{Daftar Pustaka}

[1] Hartanto H. Keluarga berencana dan kontrasepsi Jakarta: Pustaka Sinar Harapan. 2010.

[2] BKKBN. Arah pembangunan kependudukan dan keluarga berencana: Jakarta. 2012.

[3] Departemen Kesehatan RI. Standar pelayanan kebidanan. Jakarta: Departemen Kesehatan RI. 2001.

[4] Soelasih Y. Analisis tingkat kepuasan mahasiswa tern sarana prasarana FE Unika Atma Jaya. Jurnal aplikasi manajemen Volume 3, Nomor 3. Desember. 2005.

[5] Prodi D3 Kebidanan Unissula. Laporan akademik mahasiswa.2010.

[6] P Afzar. Pre-service midwifery education program in Afganistan. Final phase one report. United State Agency for International Development (USAID). diakses tanggal 20 Juli 2012 melalui http://unfpaorg. Afganistan. 2009.

[7] Undang-Undang RI No. 14 tahun 2005. tentang Guru dan dosen.

[8] Githa I Wayan. Kontribusi iklim sekolah, konsep diri dan motivasiberprestasi terhadap prestasi belajar perawatan kesehatan masyarakat (tesis). Program Pasca Sarjana IKIP Negeri Singaraja. 2004.

[9] Sudjana N. Penilaian hasil proses belajar mengajar. Bandung: PT Remaja Rosdakarya. 2011.

[10] Sandjojo N. Metode analisis jalur (path analisis) dan aplikasinya. Jakarta: Pustaka Sinar Harapan. 2011

[11] Arikunto S. Prosedur penelitian suatu pendekatan praktik. Edisi Revisi VI ed. Jakarta: PT Rineka Cipta. 2006.

[12] Sahyar. Pengaruh kompetensi dosen dan proses pembelajaran terhadap kepuasan mahasiswa. Pekbis. 2009;1:131-9.
[13] Marhawati. Pengaruh kompetensi profesional terhadap kinerja dosen pada fakultas ekonomi Universitas Negeri Makasar. 2006.

[14] Undang -undang No.20 tahun 2003. Sistem pendidikan nasional.

[15] Nirwana. Hubungan aspirasi, persepsi, lokus kendali lingkungan belajar, dan kegiatan belajar dengan prestasi belajar mahasiswa Universitas Negeri Padang. 2006.

[16] Ramainas. Pembelajaran motivasi belajar dan persepsi tentang media pembelajaran terhadap hasil belajar Universitas Negeri Padang. Jurnal Pendidikan. 2006;01:29.

[17] Pusdiknakes. Pedoman operasional sistem kredit pada sekolah dan akademi di lingkungan Depkes RI. Jakarta. 2003.

[18] Harniasih. Pengaruh prestasi belajar akuntansi keuangan, minat, dan lingkungan belajar terhadap prestasi belajar analisis laporan keuangan mahasiswa pendidikan akuntansi fakultas Ilmu Sosial Universitas Negeri Semarang.2005.

[19] Slameto. Belajar dan faktor-faktor yang mempengaruhinya. Rineka Cipta: Jakarta. 2003.

[20] Dimyati, Mudjiono. Belajar dan pembelajaran. PT Rineka Cipta: Jakarta. 2010; 26-30 